Bangladesh J. Bot. 41(2): 163-167, 2012 (December)

\title{
GENETIC VARIABILITY AND TRAIT RELATIONSHIP IN CHERRY TOMATO (SOLANUM LYCOPERSICUM L. VAR. CERASIFORME (DUNNAL) A. GRAY)
}

\author{
MS IsLAM ${ }^{1}$, HC MOHANTA, MR IsMAIL $^{2}$, MY RAFII $^{2}$ AND MA MALEK ${ }^{* 2,3}$ \\ Tuber Crops Research Centre, Bangladesh Agricultural Research Institute, \\ Gazipur, Bangladesh
}

Key words: Cherry tomato, GCV, PCV, Heritability, Genetic advance

\begin{abstract}
Nine traits of 11 cherry tomato (Solanum lycopersicum L.) var. cerasiforme (Dunal) A. Gray) inbred lines exhibited a wide range of genetic variability. High geno- and phenotypic coefficients of variation were obtained for individual fruit weight ( 68.16 and $74.23 \%$, respectively) followed by number of fruits/plant ( 58.8 and $68.34 \%$, respectively). High estimates of heritability, genetic advance and genotypic coefficient of variation for the traits of individual fruit weight, number of fruits and clusters/plant were controlled by additive gene action indicating the possibility of selection to improve these characters. Fruit yield/plant showed low heritability along with low genetic advance and did not show significant and positive correlation with the remaining characters. It indicates that improvement of high yield through selection is difficult, rather hybridization can be effective for improving the fruit yield/plant. Among the lines, $\mathrm{CH} 154$ produced the highest number of fruits/plant (291) and highest fruit yield (1.89 kg/plant and $63.4 \mathrm{t} / \mathrm{ha})$ and can be selected for cultivation under Bangladesh condition.
\end{abstract}

\section{Introduction}

Cherry tomato (Solanum lycopersicum L. var. cerasiforme (Dunal) A. gray) is a cultivated variety of tomato. The variety is generally considered to be similar but not identical to the wild relatives of the domestic tomato. It has become more popular all over the world because of a good source of vitamins A and $\mathrm{C}$, solids content, good taste and fruit set even at high temperature (Prema et al. 2011b). Its fruits are consumed more as a fruit rather than as a vegetable. Cherry tomato often called 'salad tomato' and is the probable ancestor of the cultivated tomato. Though cherry tomato became popular as a cash crop in some Asian countries is still new in Bangladesh. It is, therefore, essential to assess the quantum of genetic variability, nature of character association with respect to different characters, which would help plant breeders in planning a successful breeding programme. Genetic parameters like genotypic coefficient of variation (GCV), phenotypic coefficient of variation (PCV), heritability and genetic advance are useful biometrical tools for determination of genetic variability. The yield is a complex character, quantitative in nature and an integrated function of a number of component traits. Therefore, selection for yield per se may not be much rewarding unless other yield attributing traits are taken into consideration. Correlation study provides a measure of association between characters and helps to identify important characters to be considered while making selection. Knowledge of correlation between yield and other characters is helpful in selecting suitable plant type.

In the agro-ecological perspective of Bangladesh, information regarding variability on cherry tomato needs to be studied for a successful breeding programme to breed new varieties. Therefore,

*Author for correspondence: <mamalekbina@yahoo.com>. ${ }^{1}$ Department of Horticulture, Sylhet Agricultural University, Sylhet-3100, Bangladesh. ${ }^{2}$ Institute of Tropical Agriculture, Universiti Putra Malaysia, 43400 UPM Serdang, Selangor, Malaysia. ${ }^{3}$ Plant Breeding Division, Bangladesh Institute of Nuclear Agriculture, Mymensingh-2202, Bangladesh. 
11 cherry tomato inbred lines were collected from Asian Vegetable Research and Development Center (AVRDC), Taiwan. These were evaluated for genetic variability, heritability and correlations among the characters with a view to breeding new varieties in Bangladesh.

\section{Materials and Methods}

The experiment was conducted at Agriculture Research Station, Pahartali, Chitagong during Rabi season of 2003-2004 with 11 cherry tomato inbred lines collected from AVRDC, Taiwan. The experiment was conducted in RCB design with three replications. Seeds were sown on 2 October, 2003 in seedbed and transplanted in the field on 28 October, 2003. Land was prepared properly and fertilized with cow-dung, urea TSP, MP at the rate of 15 ton, 350,440 and $250 \mathrm{~kg} / \mathrm{ha}$, respectively. Entire amount of cow-dung TSP and MP were applied during land preparation while urea was top dressed twice at 30 and 45 days after transplanting. Unit plot size was $1.0 \mathrm{~m} \times 4.8 \mathrm{~m}$ with space at $60 \mathrm{~cm} \times 40 \mathrm{~cm}$ between row to row and plant to plant, respectively. Irrigation, weeding and other intercultural operations were done as and when necessary. Ten plants were selected randomly from each plot for collecting data on growth and yield attributes for statistical analysis.

The analysis of variance for each of the characters was performed using MSTAT software. The genotypic and phenotypic variances were estimated as per Johnson et al. (1955). Geno- and phenotypic coefficients of variation were calculated following Burton and Devane (1953). The expected genetic advance for different characters was estimated as per Johnson et al. (1955). Estimating of genetic advance as percentage of mean was calculated following Comstock and Robinson (1952). The simple correlation coefficient was done following Panse and Sukhatme (1967).

\section{Results and Discussion}

Inbred lines were found to differ significantly among themselves for all the characters except total soluble solids (TSS) (Table 1). A wide range of variation was observed in respect to days to first flower. Inbred CH157 required only 50.5 days to first flower while the highest of 63.5 days was required for CLN1555A. Wider variation in respect to days to first flower was also reported by Prema et al. (2011b) among six cherry tomato lines. Some of the inbred lines produced very tall plants. Among the inbreds, CLN1558A was the tallest in height $(154 \mathrm{~cm})$ followed by CLN1558B $(131 \mathrm{~cm})$ and CLN1555B $(129 \mathrm{~cm})$. Inbred CH152, CH157 and CH155 were found determinate in growth habit. Inbred $\mathrm{CH} 155$ had the highest number of 39.8 clusters/plant while CLN1555A had the lowest number (12.25). The highest number of fruits/plant was recorded in CH154 (291) closely followed by CH157 (281) and CH155 (280). The lowest number of fruits/plant was recorded in CLN1555A (44). Individual fruit weight ranged from $5.6-36.5 \mathrm{~g}$. Though inbred $\mathrm{CH} 154$ produced smaller individual fruit $(7.0 \mathrm{~g})$ but its fruit yield/plant was the highest $(1.89 \mathrm{~kg})$ due to higher number of fruits/plant. The second highest fruit yield/plant $(1.82$ $\mathrm{kg}$ ) was recorded in CLN1555C. In respect to fruit yield/ha, inbred CH154 produced the highest fruit yield (64.3 t/ha) while it was the lowest (42.2 t/ha) in CH151. A wide range of yield/plant and yield/ha (1.57 to $4.25 \mathrm{~kg} /$ plant and 27.91 to $75.55 \mathrm{t} / \mathrm{ha}$, respectively) was also reported in six cherry tomato lines by Prema et al. (2011b). Fruit size in respect of fruit length and fruit breadth, the line CLN1555A had the biggest fruit $(5.33 \mathrm{~cm} \times 4.5 \mathrm{~cm})$ while the line $\mathrm{CH} 155$ had the smallest fruit $(3.0 \mathrm{~cm} \times 2.05 \mathrm{~cm})$. The highest total soluble solid was recorded from the line CH155 (5.7\%) followed by CLN1555A (4.9\%).

The extent of variability in respect to nine different characters among the inbreds measured in terms of range, genotypic coefficient of variation (GCV), phenotypic coefficient of variation 
(PCV) along with heritability, genetic advance and genetic advance (in per cent of mean) are presented (Table 2). In general, phenotypic coefficient of variation (PCV) was higher than GCV in

Table 1. Yield and yield attributes of 11cherry tomato inbred lines.

\begin{tabular}{lllllllllll}
\hline Inbred & $\begin{array}{c}\text { Days to } \\
\text { first } \\
\text { lines }\end{array}$ & $\begin{array}{c}\text { Plant } \\
\text { height } \\
(\mathrm{cm})\end{array}$ & $\begin{array}{c}\text { Clusters/ } \\
\text { plant } \\
(\text { No. })\end{array}$ & $\begin{array}{c}\text { Fruits/ } \\
\text { plant } \\
(\text { No. })\end{array}$ & $\begin{array}{c}\text { Weight/ } \\
\text { fruit } \\
(\mathrm{g})\end{array}$ & $\begin{array}{c}\text { Fruit } \\
\text { yield/ } \\
\text { plant }(\mathrm{kg})\end{array}$ & $\begin{array}{c}\text { Fruit } \\
\text { yield/ } \\
\text { ha }(\mathrm{t})\end{array}$ & $\begin{array}{c}\text { Fruit } \\
\text { length } \\
(\mathrm{cm})\end{array}$ & $\begin{array}{c}\text { Fruit } \\
\text { breadth } \\
(\mathrm{cm})\end{array}$ & $\begin{array}{c}\text { Total } \\
\text { soluble } \\
\text { solid }(\%)\end{array}$ \\
\hline CLN1558A & $60.0 \mathrm{ab}$ & $154 \mathrm{a}$ & $20.1 \mathrm{bc}$ & $114 \mathrm{a}-\mathrm{c}$ & $15.7 \mathrm{bc}$ & $1.77 \mathrm{ab}$ & 60.2 & $3.50 \mathrm{c}$ & $2.43 \mathrm{c}$ & 4.65 \\
CLN1558B & $60.0 \mathrm{ab}$ & $131 \mathrm{ab}$ & $13.9 \mathrm{c}$ & $106 \mathrm{a}-\mathrm{c}$ & $12.0 \mathrm{c}$ & $1.51 \mathrm{bc}$ & 51.3 & $3.51 \mathrm{c}$ & $2.93 \mathrm{c}$ & 3.6 \\
CLN1555A & $63.5 \mathrm{a}$ & $130 \mathrm{ab}$ & $12.3 \mathrm{c}$ & $44 \mathrm{c}$ & $33.0 \mathrm{a}$ & $1.34 \mathrm{bc}$ & 45.6 & $5.33 \mathrm{a}$ & $4.5 \mathrm{a}$ & 4.9 \\
CLN1555B & $57.0 \mathrm{a}-\mathrm{c}$ & $129 \mathrm{ab}$ & $15.0 \mathrm{c}$ & $49 \mathrm{c}$ & $36.5 \mathrm{a}$ & $1.77 \mathrm{ab}$ & 60.2 & $4.82 \mathrm{ab}$ & $4.13 \mathrm{a}$ & 3.65 \\
CLN1555C & $54.5 \mathrm{bc}$ & $117 \mathrm{a}-\mathrm{c}$ & $13.8 \mathrm{c}$ & $64 \mathrm{c}$ & $30.5 \mathrm{a}$ & $1.82 \mathrm{ab}$ & 61.9 & $5.04 \mathrm{a}$ & $4.03 \mathrm{ab}$ & 3.6 \\
CLN1561A & $61.5 \mathrm{ab}$ & $125 \mathrm{ab}$ & $16.0 \mathrm{c}$ & $94 \mathrm{bc}$ & $16.0 \mathrm{bc}$ & $1.47 \mathrm{bc}$ & 50.0 & $3.87 \mathrm{bc}$ & $3.04 \mathrm{bc}$ & 4.05 \\
CH151 & $58.0 \mathrm{a}-\mathrm{c}$ & $117 \mathrm{a}-\mathrm{c}$ & $37.5 \mathrm{ab}$ & $139 \mathrm{a}-\mathrm{c}$ & $10.2 \mathrm{c}$ & $1.24 \mathrm{c}$ & 42.2 & $3.32 \mathrm{c}$ & $2.42 \mathrm{c}$ & 4.25 \\
CH152 & $52.0 \mathrm{c}$ & $71 \mathrm{c}$ & $34.9 \mathrm{ab}$ & $220 \mathrm{a}-\mathrm{c}$ & $6.5 \mathrm{c}$ & $1.45 \mathrm{bc}$ & 49.3 & $3.16 \mathrm{c}$ & $2.15 \mathrm{c}$ & 4.6 \\
CH154 & $54.5 \mathrm{bc}$ & $106 \mathrm{a}-\mathrm{c}$ & $42.4 \mathrm{a}$ & $291 \mathrm{a}$ & $7.0 \mathrm{c}$ & $1.89 \mathrm{a}$ & 64.3 & $3.45 \mathrm{c}$ & $2.71 \mathrm{c}$ & 4.4 \\
CH157 & $50.5 \mathrm{c}$ & $83 \mathrm{bc}$ & $34.2 \mathrm{ab}$ & $281 \mathrm{ab}$ & $6.0 \mathrm{c}$ & $1.69 \mathrm{ab}$ & 57.5 & $3.33 \mathrm{c}$ & $2.59 \mathrm{c}$ & 4.2 \\
CH155 & $54.5 \mathrm{bc}$ & $96 \mathrm{bc}$ & $39.8 \mathrm{a}$ & $280 \mathrm{ab}$ & $5.6 \mathrm{c}$ & $1.58 \mathrm{bc}$ & 53.7 & $3.04 \mathrm{c}$ & $2.05 \mathrm{c}$ & 5.7 \\
F-test & $* *$ & $* *$ & $* *$ & $* *$ & $* *$ & $*$ & $*$ & $* *$ & $* *$ & NS \\
CV \% & 3.9 & 12.9 & 21.1 & 36 & 29.4 & 18.2 & 14.7 & 7.7 & 10.6 & 25.7 \\
\hline
\end{tabular}

Same letter(s) in a column did not differ significantly at $\mathrm{p} \leq 0.05$ by DMRT; $*$ and $* *=$ Significant at 5 and $1 \%$ level of probability, respectively; NS = Not significant.

Table 2. Estimates of mean, range, genotypic and phenotypic variances, genotypic and phenotypic coefficient of variations, heritability and genetic advance in cherry tomato.

\begin{tabular}{llllllllll}
\hline Characters & Range & Mean & GV & PV & $\begin{array}{l}\text { GCV } \\
(\%)\end{array}$ & $\begin{array}{l}\text { PCV } \\
(\%)\end{array}$ & $\begin{array}{l}\mathrm{h}^{2} \\
(\%)\end{array}$ & GA & $\begin{array}{l}\text { GA } \\
(\% \text { of } \\
\text { mean })\end{array}$ \\
\hline Days to 1st flower & $52.0-63.5$ & 56.9 & 14.3 & 19.12 & 6.64 & 7.69 & 75 & 7.2 & 12.7 \\
Plant height & $71.4-153.6$ & 114.45 & 454 & 673 & 18.62 & 22.66 & 68 & 39.4 & 34.4 \\
Cluster/plant (No.) & $13.9-42.4$ & 25.44 & 133 & 162 & 45.33 & 50.01 & 82 & 22.6 & 88.7 \\
Fruits/plant (No.) & $44-291$ & 153 & 7885 & 10914 & 58.08 & 68.34 & 72 & 167.5 & 109.6 \\
Weight/fruit (g) & $5.6-36.5$ & 16.28 & 123 & 146 & 68.16 & 74.23 & 84 & 21.9 & 134.3 \\
Fruit yield/plant (kg) & $1.24-1.89$ & 1.59 & 0.027 & 0.086 & 12.4 & 18.49 & 31.4 & 0.12 & 7.5 \\
Fruit yield/ha (t) & $42.2-64.3$ & 54.2 & 11.3 & 38.7 & 9.23 & 13.21 & 29.2 & 5.8 & 10.7 \\
Fruit length (cm) & $3.04-5.00$ & 3.85 & 0.215 & 1.1 & 12.04 & 27.3 & 19.45 & 0.54 & 14.2 \\
Fruit breadth (cm) & $2.05-4.50$ & 3 & 0.66 & 0.76 & 27.08 & 29.03 & 86.84 & 1.61 & 53.8 \\
Total soluble solid & $3.6-5.7$ & 4.33 & 0.21 & 1.03 & 21.01 & 23.43 & 20.38 & 0.67 & 15.6 \\
(TSS) (\%) & & & & & & & & & \\
\hline
\end{tabular}

all the traits. GCV and PCV were high for individual fruit weight and number of fruit/plant (68.16 and $74.23 \%$, and 58.08 and $68.34 \%$, respectively). High values of GCV and PCV were also observed in number of clusters/plant (45.33 and 50.01\%), fruit breadth $(27.08$ and $29.03 \%)$ and total soluble solid (21.01 and 23.043\%). The present results i.e., high estimates of phenotypic and genotypic coefficients variation $(>20 \%)$ for different characters are in agreement with the results reported by Anjum et al. (2009) in tomato and Prema et al. (2011a) in cherry tomato. Lower GCV 
and PCV were obtained for days to first flower (6.64 and 7.69\%) and fruit yield/plant (3.14 and $18.49 \%$ ). Fruit breadth, individual fruit weight, number of clusters/plant, days to first flower and number of fruits/plant exhibited high heritability estimates $(87,84,82,75$ and $72 \%$, respectively), indicating that these characteristics are less influenced by the environment. Genetic advance (GA) in per cent of mean was very high for individual fruit weight (134.3\%) followed by number of fruits/plant (109.6\%) and number of clusters/plant (88.7\%), whereas this estimate was the lowest for fruit yield/plant (7.5\%) followed by fruit yield/ha (10.7\%).

Heritability, genetic advance and genotypic coefficient of variation together could provide the best image of the amount of advance to be expected from selection (Johnson et al. 1955). In case of individual fruit weight, number of fruits/plant and number of clusters/plant, high values of GA, heritability and GCV indicated that these characteristics were controlled by additive gene action and the selection based on phenotype for these traits might be effective. Similarly high heritability coupled with moderate GA and GCV for fruit breadth suggested that selection might be effective for this trait. However, high heritability but low GA and low GCV for days to first flower showed the involvement of non-additive gene action and the selection upon this character might not be promising. Characters with low heritability with low genetic advance can be improved through hybridization (Liang and Walter 1968, Anjum et al. 2009). Therefore, the traits like yield/plant and yield/ha of cherry tomato can only be improved through hybridization since both traits produced low heritability along with low genetic advance.

Table 3. Phenotypic correlation coefficient among different characters of cherry tomato inbred lines.

\begin{tabular}{lcccccccc}
\hline Traits & $\begin{array}{c}\text { Plant } \\
\text { height }\end{array}$ & $\begin{array}{c}\text { Clusters/ } \\
\text { plant }\end{array}$ & $\begin{array}{c}\text { Fruits/ } \\
\text { plant } \\
\text { (No.) }\end{array}$ & $\begin{array}{c}\text { Weight/ } \\
\text { fruit }\end{array}$ & $\begin{array}{c}\text { Fruit } \\
\text { yield/ } \\
\text { plant }\end{array}$ & $\begin{array}{c}\text { Fruit } \\
\text { length }\end{array}$ & $\begin{array}{c}\text { Fruit } \\
\text { breadth }\end{array}$ & TSS \\
\hline Days to first flower & $0.82^{* *}$ & $-0.64^{*}$ & $-0.71^{*}$ & 0.45 & -0.40 & 0.42 & 0.43 & -0.04 \\
Plant height & & $0.67^{*}$ & $-0.72^{*}$ & 0.53 & 0.068 & 0.42 & 0.42 & -0.26 \\
Clusters/plant & & & $0.90^{* *}$ & $-0.78^{* *}$ & 0.004 & $-0.74^{* *}$ & $-0.75^{* *}$ & 0.5 \\
Fruits/plant (No.) & & & & $-0.84^{* *}$ & 0.19 & -0.76 & -0.74 & 0.48 \\
Weight/fruit & & & & & 0.11 & $0.95^{* *}$ & $0.93^{* *}$ & 0.37 \\
Fruit yield/plant & & & & & 0.092 & 0.094 & -0.22 \\
Fruit length & & & & & & & $0.98^{* *}$ & -0.34 \\
Fruit breadth & & & & & & & & -0.42 \\
\hline
\end{tabular}

$*$ and ** = Significant at 5 and $1 \%$ level of probability, respectively.

Phenotypic correlation coefficients for all pairs of nine characteristics are presented (Table 3). The highest positive correlation coefficient was observed between fruit length and fruit breadth $\left(\mathrm{r}=0.98^{* *}\right)$; individual fruit weight and fruit length $\left(\mathrm{r}=0.95^{* *}\right)$. Number of fruits/plant is an important parameter for high yield. This parameter is significantly correlated with number of clusters/plant $\left(\mathrm{r}=0.90^{* *}\right)$. On the contrary, the number of fruits/plant was negatively correlated with individual fruit wt $\left(-0.84^{* *}\right)$, fruit length $\left(-0.76^{*}\right)$ and fruit breadth $\left(-0.74^{* *}\right)$. This is why number of fruits/plant was not significantly correlated with number of fruit yield/plant. Some other characters such as number of clusters/plant, individual fruit weight, fruit length, fruit breadth had no significant correlation with fruit yield/plant. The present results show similarity with the results reported by Mohanthy (2003) in tomato. 


\section{References}

Anjum A, Raj N, Nazeer A and Khan SH 2009. Genetic variability and selection parameters for yield and quality attributes in tomato. Indian J. Hort. 66(1): 73-78.

Burton GW and Devane EH 1953. Estimatig heritability in tall fescue (Festuca arundiaceae) from replicated colonial material. Agron. J. 45: 478-481.

Comstock RE and Robinson HF 1952. Genetic parameters, their estimation and significance. Proc. 6th Intern. Grassland Cong. 1: 248-291.

Johnson HW, Robinson HE and Comstock RE 1955. Estimates of genetic and environmental variability in soybeans. Agron. J. 47: 314-318.

Liang GHL and Walter TL 1968. Heritability estimates and gene effect for agronomic traits in grain sorghum. Crop Sci. 8: 77-80.

Mohanthy BK 2003. Genetic variability, correlation and path coefficient studies in tomato. Indian J. Agric. Res. 37(1): 68-71.

Panse VG and Sukhatme PV 1967. Statistical method for Agricultural workers. $2^{\text {nd }}$ Ed. Indian Council of Agricultural Research, New Delhi. p. 381.

Prema G, Indiresh KK and Santosha HM 2011a. Studies on genetic variability in cherry tomato (Solanum lycopersicum var. cerasiforme). Asian J. Hort. 6(1): 207-209.

Prema G, Indiresh KK and Santosha HM 2011b. Evaluation of cherry tomato (Solanum lycopersicum var. cerasiforme) genotypes for growth, yield and quality traits. Asian J. Hort. 6(1): 181-184.

(Manuscript received on 14 February, 2012; revised on 10 November, 2012) 